\title{
THE POLITICAL AND ECONOMIC HISTORY OF NORTH CYPRUS
}

\author{
Ihsan Seddar KAYNAR* \\ The Political and Economic History of North Cyprus: A Discordant Polity, by Tufan Ekici, \\ Cham, Switzerland, Palgrave Studies in Economic History, 2019, 326 pp, ISBN 978-3-030- \\ 13478-5; 103,99€ (pbk), ISBN 978-3-030-13479-2; 58,84€ (eBook)
}

\section{An overview}

Tufan Ekici's 'The Political and Economic History of North Cyprus' is published in 2019 by Palgrave Macmillan as a part of Studies in Economic History series. It deals with 44years old north Cyprus government, which emerged after division of the island in 1974. Examining the political organization and structure of the government, labour market, state economic enterprises, and allocation of land, Ekici sheds light on the turbulent history of the political apparatus of north Cyprus. The 283-page book consists of nine chapters, and it is the first book-length analysis on the economic history of that part of the island. The book addresses many significant questions such as the relation between Turkey and the north Cyprus, economic development across the Cyprus, and identity of the possible perpetrators of pre-1974 violent incidents. As explained in more detail in Chap. 2, the territory of the Turkish government in north Cyprus is an artificial construction, came to existence out of one third of the island on the northern coast, where would be Turkified after the division. Turkish government in the north transformed itself into an independent state on November 15, 1983. Nevertheless, it lacks international political recognition, except Turkish Republic, and exists as a de facto state since that day. The negligence of international community is coupled with that of scholarly literature as there are few studies on the economic and political history of the north Cyprus. In that respect, Ekici's book is an important contribution to Cyprus Studies and Turkey's role in north Cyprus' economic and political affairs.

The architecture of the book progresses step by step. The narrative and the arguments of the book proceeds from one chapter to the next, suggesting that when a chapter is selected and read randomly, the unity of the book is disrupted. Additionally, a quick glance at the content of the book shows that some main topics of the mainstream economic history approaches such as capital accumulation is left out. However, the author convinces the reader in Chap. 1 that depicting 44-years old political and economic history of the north Cyprus could not be done satisfactorily in a traditional way. When talking about Cyprus, the biggest problem is political terminology. Referring to Turkey's military operations in 1974, Greek Cypriots use the word 'invasion' and Turkish Cypriots prefer the term 'peace operation'. Throughout the book, the author choses a less normatively loaded and more technical term 'intervention', conveying neither approval nor condemnation of Turkey's conduct.

The author is very impressed by Daron Acemoğlu and James Robinson's book 'Why Nations Fail?'. Especially the city Nogales on the US-Mexico border inspired him deeply. Nogales was on both sides of the fence, where two groups of people with similar cultures, traditions and geographic resources lived, but the level of economic development of the two sides differed from each other vastly. Ekici used this example in his book to illustrate the northsouth divide in Cyprus. In the similar vein, in his analysis of the failure of the northern Turkish government, Ekici arrives to the same conclusion that Acemoğlu and Robinson drew for many

\footnotetext{
* Assist. Prof. Dr., Hakkari University, Faculty of Economics and Administrative Sciences, Department of Economic History, seddar@gmail.com, ORCID: 0000-0003-3446-2310
} 
different states across the World: lack of institutional development. For him, there are significant differences in the institutional development between two sides of the Island since the division in 1974. Throughout the book Ekici shows how the parliament, courts, civil sector and policymakers have been spreading clientelistic politics and a corrupt polity in the north.

Chap. 1 describes the system of governance in north Cyprus. Since the author was born and raised in the island, he is able to depict clearly how problems started to arise after division of the Island. Hence, Ekici's own observations and experiences about daily life and governance are the main sources that used when penning this chapter. For those who are unfamiliar with Cypriot studies, the last part of this chapter provides a brief history of the Island before 1974, with a focus on British colonialism as the entire island was ceded from the Ottomans to Britain in 1878 and stayed as a part of the Common Wealth until 1960.

The Chap. 2 has the title 'What Kind of Polity?'. Here, Ekici explains the conceptual and theoretical framework that the book uses to examine the post-1974 period of north Cyprus' political and economic history. These concepts and theories also serves as the guides for a more detailed sectoral analysis, which makes up the majority of the book. After 1974 intervention, Turkish Cypriot leaders started to establish state institutions in order to maintain an independent administration in the northern part of the island, not knowing that de facto separation in 1974 would turn into a permanent reality. Ekici underlines that irrespective of whether North Cyprus is a de facto or de jure state since 1983 or whether the governments are motivated by clientelistic or rent-seeking principles, the officials involved in the management of north Cyprus political apparatus have done an incredibly poor job over the last 44 years. At the end of Chap. 2 , he pays attention to British colonialism one more time, yet he does not establish any connection between island's colonial past and the present problems. On the contrary, Ekici insists that only those who live in and rule the north Cyprus are responsible for post-1974 developments. However, British colonialism provides an important background to many developments in the north Cyprus, especially to the economic problems that the island still tackles with.

How public governance of Turkish Cypriots emerged right after the intervention of Turkey to the island in August 1974 and changed in time is explained in the Chap. 3. The chapter touches upon the role of important figures such as Rauf Denktaş, Mehmet Ali Talat, Özker Özgür, and Derviş Eroğlu in shaping the political history of North Cyprus. However, the main emphasis is on institutions. Ekici starts his institutional analysis with the examination of the parliament, ministries and municipalities, which are the main institutions of representative democracy. He explains how politics in the northern part acquired pace through the establishment of political parties. In this respect, 'The Political Parties and the Early Years' is an excellent sub-section. The reader can clearly see how political and economic issues are intertwined with each other while reading this section. The basic institutional framework of the Turkish Cypriot government was established by the end of the 1980s. Ekici first tells us the legal regulations that affected the first accumulation in the north Cyprus, and highlights how these regulations would determine the future developments. Afterwards, he demonstrates that creation of Turkish bureaucracy relied heavily on sharing of the spoils of war, which accepted by the consensus of all political organs and approved jointly by the right and left wing parties of the time. It is significant that the legal basis of distribution of spoils of war, the so-called "ITEM" Law' (Law for Housing, Allocation of Land and Property of Equal Value), was prepared with the participation and consent of all segments of north Cypriot polity. In addition, the ITEM law provided the key instrument of clientelism and can be considered as the beginning of rentierism in north Cyprus.

Chap. 4 entitled 'From Separation to Convergence: The Economic Development of the Republic of Cyprus and the Turkification of Northern Cyprus' depicts how international isolation of the North Cypriot government and its dependence to Turkey turned into a chicken and egg situation. After 1974 the north Cyprus approached more and more to Turkey, which 
Ekici calls 'convergence'. The main reason of this convergence was international isolation of the Northern government, more clearly, its recognition by Turkey and closure to the rest of the world. In bureaucratic or economic affairs, Turkey was the only country that North Cypriot government was able to establish relations. However, it should be stated that establishing relations with Turkey is quite different from receiving unconditional aid from her. The North Cypriot governments not only developed close relations with Turkey, they received and continue to receive considerable aid from Turkey, which proved to have controversial effects in the long run. On the one hand, it let the North Cyprus survive, on the other; it made the northern part remain permanently dependent to Turkey. In this respect, Ekici skilfully handles this double function of Turkish aid in this relatively short part.

Chap. 5 entitled 'The Labour Market' examines the creation of jobs in the state sector. Ekici questions how the state became the main employee and why the private sector remained weak. Accordingly, after division of the island, there were around 30,000-35,000 refugees from the south Cyprus, who were mainly farmers. Subsequently, approximately 60,000 settlers arrived to the island from Turkey, who were distributed around the north Cyprus and constituted the majority of the new labour force (p.123). It is clear that North Cyprus do not need migrants as its economy can hardly absorb any extra labour force. These Anatolian people not as immigrants, but as an important step in the Turkification of northern Cyprus. The state undertook two key measures to deal with the impact of new comers on labour market. The first was to provide employment for many displaced Turkish Cypriots in civil services and at stateowned enterprises. Priority was given to those who came to the north from the south. So, many Turkish Cypriots who were previously working in the agricultural sector were made state officials. The second measure was to allocate agricultural land and accommodation to settlers from Turkey, so that they could settle and contribute to economic growth of the government. Hence, people coming from Turkey were directed to rural areas for agricultural production.

Meanwhile, a key demographic change that affected the labour market was the outmigration of Turkish Cypriots. First, many Turkish Cypriots migrated to Britain as it was simple to obtain a work and residence permit there because of Cyprus' commonwealth past. Second, they migrated to the Greek part of the island. The first crossing point across the islandwide buffer zone, mediated and controlled by the United Nations, was opened in April 2003. After that date, there was a significant labour movement from north to the south. The wages in the south were higher than the northern part, which gave an incentive to many people without a steady job to look for employment opportunities in the south. Nevertheless, such an opportunity was only for Turkish Cypriots (and other EU nationals), and not for other immigrants or nationals such as those coming from Turkey, Arabs or Asians.

Another issue that the book handles is unionism. Cyprus used to have strong trade unions since the 1920s. Most union activities were carried out jointly by Greek and Turkish Cypriots against British colonial government's exploitation of workers. For instance, the struggle of Greeks and Turks together in the mines of Lefke in 1948, which lasted 125 days should be remembered. Over the time, class consciousness was replaced by nationalism, yet this change did not decrease the prevalence of trade unions. Ekici discusses the disorganization of Cyprus' strong union structure and the development of trade unions in north Cyprus in order to show how the labour market, particularly in the public sector, evolved.

Public employment in state economic enterprises (SEEs) is discussed in Chap. 6, entitled 'Social Security System'. Chap. 6 shows the historical development of pension systems and assesses their significance for the north Cyprus. Over the years, the governments have modified the laws to serve their own interests without considering the impact of pension systems for future generations. The result was a failed social security system and a huge financial burden on future taxpayers. Related to this point, Chap. 7 entitled 'State Economic Enterprises and Revolving-Capital Enterprises' has two subsections. In Chap. 7, Ekici attempts to cover all economic institutions founded by the government as a part of his institutional 
analysis. Accordingly, the SEEs were established mainly in agricultural, energy and financial sectors. Their names are Cyprus Turkish Airlines (KTHY), Turkish Cypriot Industrial Holding Company (Sanayi Holding), Turkish Cypriot Tourism Establishments (Kıbrıs Türk Turizm İşletmeleri), Turkish Cypriot Tobacco Industry (Kıbrıs Türk Tutun Endustrisi), Cyprus Turkish Petroleum (Kıbrıs Türk Petrolleri), Cyprus Turkish Maritime (Kıbrıs Türk Denizcilik Sti. Ltd), Cypfruvex (Cyprus Fruit and Vegetable Exports). They were intended to provide significant employment opportunities and be alternatives to civil service posts. Additionally, as the SEEs contributed to domestic production, such employment was provided by using minimum sources from the central budget. However, in time these enterprises proved to be a huge burden on the government, and some of them went bankruptcy or were sold to the private sector. One of the most important contributions of the book is that it allows the reader to see how left and right wing politicians of the period approached this issue.

On the surface, the SEEs were strong, autonomous establishments, yet actually they were institutionally very weak and vulnerable to market forces. In this regard, the story of Cypfruvex (Cyprus Fruit and Vegetable Exports), which Ekici gives place under the first subsection of Chap. 7 entitled 'Individual Histories of Some of the SEEs', worth telling. Cypfruvex was specialized in the export of citrus fruit products. When a private firm (Sunzest), owned by businessman Asil Nadir, started to operate in this field, the Cypfruvex very quickly lost its connection with the local producers, and the market share and the value of the company decreased substantially. Sunzest increased its market share from 30 percent of all citrus fruit exports in 1986 to 72 percent in 1990, whereas Cypfruvex's share of exports decreased from 37 percent to 18.7 percent. The main reason of this change is that Sunzest paid the producers more and in advance, rather than Cypfruvex, which paid the producers a portion in advance and the rest after exportation of the products.

After examining some of the biggest SEEs of the north Cyprus in a historical perspective, Ekici shows how rentierism, rent-seeking behaviour and endemic clientelistic policies dominated the government. When Ekici searches for the reasons of rentierism and clientelism, one more time North Cyprus' relation with Turkey reveals itself. Ekici states that in the establishment and operation of every SEE, one can see the footprints and role of Turkey. The SEEs were established with the financial aid that Turkey allocated to the northern government. Besides, they had shared ownership with the state-owned enterprises of Turkey, and administered by the bureaucrats who came from Turkey. In this part, it would be more informative if the author had told how these enterprises, embedded in complex relations, operate and affect production and income distribution in the Island. However, Ekici gives more importance to the stories of their collapse, possibly because they are more tragic. Nevertheless, this preference creates a pessimistic atmosphere that sometimes bores the reader.

The main topic of the second subsection 'Revolving-Capital Establishments' of Chap. 7 is how the SEEs sustained themselves through a revolving-capital fund and only partly managed by the elected state officials. There were five semi-state-owned organizations. Four of them operated in the agricultural sector, and the fifth was in the energy sector. Although they were all subject to the laws of Company Registration, the parliament passed separate laws for each regarding their management and operations. Each of these companies was responsible for their own finances, but they could also receive transfers from the state's budget. They all provided significant employment opportunities and had great economic potential, but inappropriate policies caused their failure. Their names are Milk Industry Board (Sut Endustrisi Kurumu, SUTEK), Cyprus Turkish Electricity Board (Kıbrıs Türk Elektrik Kurumu, KIBTEK), Agricultural Supply Board (Tarimsal Donatim Kurumu, TDK), Agricultural Products Board (Toprak Urunleri Kurumu, TUK) and State Hatchery (Devlet Uretme Ciftlikleri).

One of the five semi-state-owned organizations is Milk Industry Board (Süt Endustrisi Kurumu, SUTEK). The main objective of the SUTEK was to regulate the domestic milk market as effectively as possible. In principle, it was possible for a farmer to sell milk to SUTEK and 
then go back and buy the same milk at a cheaper price and produce cheese or other milk products. One restriction was that the rules required registry by SUTEK in order to be paid for the milk purchased. Ekici explains that many civil servants registered their relatives as the owners of the animals to cheat the law since it was prohibited for civil servants to work in a second job. After telling this problem, Ekici rightly challenges the claim that north Cyprus broke its ties with the countryside and completely chose the path of urban development. Ekici's point shall be underlined: although main source of employment was state, state officials kept their ties with the village; they had relatives, fields and animals in their villages.

The book is full with examples of how the SEEs were badly managed since their establishment. Politicians have used these enterprises to provide employment to their close circles and the governments did not invest in them to protect SEEs from international competition or just to make them survive in the domestic market. On the contrary, the governments have meddled with the administration of these enterprises directly by deciding the prices, outputs and other key business issues. Borrowings from state-guaranteed banks or direct transfers from the central budget remained as the only financial resources of the SEEs. Hence, the basic conclusion is that these enterprises would have actually survived in the twenty-first century within the global market, but they were not even allowed to fully develop and not given a chance to consolidate themselves prior to neo-liberal turn. For instance, Cypfruvex could not export its products to European countries after 1994. Even so, it could still utilize them in the domestic market. Similarly, although it could not offer advanced payments to the producers, it could have worked on some alternative arrangements with the related associations regarding payments.

After explaining state sector, Chap. 8 deals with 'Private Sector Development'. It shall become obvious that because of mismanagement and corruption, the public sector could not be the key sector in economic development of North Cyprus. From this point onward, Chap. 8 seeks the answer how the private sector in north Cyprus developed after the division in 1974. The author focuses on certain selected sectors, and discusses their importance for the economy of North Cyprus. Especially, the key sectors of agriculture, tourism and education are analysed albeit limited available data. The Central Bank and the Development Bank are also discussed in this chapter as they influence the development of private sector. The year 1994 was an important turning point in the development of private sector. Decision of the European Court of Justice (ECJ) on July 5, 1994 prohibited the import of commodities produced in north Cyprus into the European Economic Community (EEC) on the ground that they didn't meet the EEC quality criteria. Being the key export sectors, agriculture and animal husbandry were heavily affected by the ECJ's decision. The ECJ's decision, which came 20 years after the division, increased dependence of north Cyprus to Turkey even more. Interestingly, Turkish Cypriot policymakers did not do anything to stop this decision being taken or did not even think about alternative means to recover the negative effects of this decision or other embargoes imposed by international community. Rather, they kept on blaming each other and Greek Cypriots for the stalled economy of north Cyprus.

Considering agricultural sector, the decision of the ECJ was not the only problem. The sector was struggling with lack of governmental support, scarce water resources, arid climate, lack of general transportation and consolidated market, and low fixed capital investment. After division of the island in 1974, about 41 percent of the labour force in the north were working in the agricultural sector. This number decreased to 21 percent in 1996, yet plummeted to 4.1 percent in 2015. Employment in farming or animal husbandry in general declined in North Cyprus over the years, where many locals in the 1980s and 1990s found jobs in the public sector, worked as self-employed or enjoyed early retirement. However, given the flexible working hours, many people continued to take care of their lands. Most people conducted farming as a second job or hobby, where they cultivated small areas of land or owned small 
number of animals. So, one can assume that the number of households receiving additional income from farming or animal husbandry is actually higher that the above statistics.

The other sector of key importance is tourism. Tourism is classified by policymakers as of high priority, and government programmes always included quite optimistic targets about this sector. After 1974, the new state appropriated substantial amount of tourist accommodation facilities and attractions. Some hotels were directly managed by the SEEs. Another group of hotels as well as apartments were rented to individuals or other entities at rather low prices. Foreign tourists were more likely to stay in touristic accommodation places, whereas Turkish tourists would tend to stay at relatives' and friends' houses. Regardless of the inconsistencies between the data, this industry is a good source of employment. Related to tourism, the casino industry is not new in north Cyprus. The first casinos were established in the early 1990s, when gambling was prohibited in Turkey. More than half of total employment in the tourism industry is accounted for by the hotel casinos. These casinos also created 'casino tourism', which includes weekend tourists (or daily tourists mostly from Turkey but more recently from south Cyprus as well), whose sole purpose is gambling.

Another important sector for the economy of north Cyprus is higher education. It is probably not fair to call higher education as a 'sector' as it would imply that the universities should be treated as firms according to traditional economic definitions. However, the higher education in north Cyprus is largely supplied by profit-maximizing institutions, and the policymakers constantly refer to higher education as the 'key economic sector'. Given that 80 percent of the students are from Turkey, the accreditation by the Council of Higher Education is very important in recognizing and validating the international status of north Cyprus' degree certificates.

As for the financial sector, the medium of exchange in the north remained as Cyprus pounds (CYP), but insofar as the new state became dependent on Turkey, the Turkish lira (TL) eventually became de facto currency of day-to-day transactions. There is no capital accumulation in Cyprus, but the banking sector has a colourful history. The first established banks were basically the old local cooperative banks and large banks of Turkey that had branches in north Cyprus. Formal regulations regarding the working of the banks did not develop immediately after the division. For many years Ziraat Bank of Turkey acted as the central bank until the bill founding the central bank and banking regulations was finally enacted in 1983. As can be presumed, the Central Bank of the Northern Cyprus was administered by bureaucrats coming from Turkey. Commercial banks are all subject to monitoring of the Central Bank. However, for a long time they continued to operate in a laissez-faire environment, as the Central Bank was not in a hurry to implement any sound monetary policy. Rather, it merely acted as an auditing mechanism for other commercial banks. Being administered by the bureaucrats of another state and avoiding from regulating the financial sector, the Central Bank of the Northern Cyprus fulfilled only the procedural requirement to make North Cyprus seem as an independent state, with an independent domestic economy and market. It is one of the institutions that is founded to form the political apparatus in north Cyprus into a state.

\section{Concluding remarks}

Cyprus is not the only territory that is being divided into two separate states. However, Cyprus is the only island that is ethnically homogeneously separated, and it is the only island that one de facto and one de jure state exists side by side. Nicosia remains as the capital of both states, which is divided into two as well. Being a de facto state with limited market opportunities, North Cyprus is immediately affected by international political and economic developments. Any change in the commercial and political relations between Europe, Great Britain, Greece and Turkey is causing great fluctuations in the island.

Post-division North Cyprus is an amalgamation of past and present, and poverty and richness. On the one hand, there are abandoned old cars and ruined buildings, on the other hand, there are luxury jeeps and three-store residences with pools and large gardens. Ekici touches 
about this contradiction when examining the dilemmas of daily life in Cyprus, the functioning of democracy and the inter-state relations in the introduction. It is clear that to identify and depict such contradictions one has to make deep observations and perhaps more than that, live in Cyprus. However, the balance between personal opinions and objective analysis should have been kept better. Ekici uses his own experiences and personal observations so much so that sometimes it is getting confusing whether we are reading a history book or listening a friend's worries and ideas. This situation becomes clearer in the Conclusion part, which is Chap. 9. An atypical conclusion part on the 2018 general election in North Cyprus and its results awaits for those who are patient to follow the book to the end. Here, Ekici reflects his disappointment and starts to criticize himself and the civil organizations that he is a member of, for the current situation of north Cyprus.

The basic point of the book is inadequacy of the governors and the corrosion of institutions, which led to lack of accountability and transparency in domestic state affairs. The Turkish Cypriot governments never carefully planned strategic policies that could have benefited economic development. On the contrary, they were busy with clientelistic and rentseeking activities and with solidifying their relationship with Turkey. Dependency relationship between Turkey and North Cyprus, on the other hand, is striking. North Cyprus is absolutely an aid-dependent state; without the financial aid regularly coming from Turkey with no reason, the North Cyprus would totally paralyzed. However, strictly speaking, North Cyprus is not a colony of Turkey as there is no palpable transfer of wealth (in terms of commodity or capital) from the island to Turkey, but the opposite. Therefore, Ekici puts the term 'colony' in parentheses (p.256) to imply this difference.

That being the case, Ekici's analytical and conceptual preferences shall be questioned more critically. His embracement of institutional perspective and analysis to explain economic and political development of North Cyprus is time to time counterproductive. As North Cyprus government is a dependent, externally enforced, and artificial political apparatus, so are their institutions. Economic institutions that Ekici mentions in the book have never subjected to free market forces, never let to live without aid, and developed institutional identity. On the contrary, they quickly degenerated and instrumentalized in the hands of the politicians. Actually, the book demonstrates how agents rather than institutions came to fore in the history of north Cyprus after 1974. Therefore, institutional analysis provides a too large and complex framework then the examination of North Cyprus government demands. Additionally, institutional analysis of Ekici engenders a static narrative of economic history, in which institutions are depicted disconnected from each other. On the one hand, the book fails to show how the agricultural sector or the economy of North Cyprus government in general changed over the years, although it successfully explains the changes occurred in labour market. On the other, the books jumps from one sector to another as if they were operating autonomously, omitting the relations and connections between them.

Lastly, the bibliography of the book is quite interesting. The book uses official data obtained from state departments and personal archives of author's relatives and friends. The book includes parliamentary debates, when important laws that left their mark in the history of North Cyprus are discussed in the parliament. Reading parliamentary debated is quite helpful in understanding the perspective of political parties on the issues. There are three major political parties in the north Cyprus, who have been governing this political apparatus about 90 percent of the time since 1975 (p.259). They are Ulusal Birlik Partisi (National Unity Party), Demokrat Parti (Democratic Party), and Cumhuriyetçi Türk Partisi (Republican Turkish Party) or 'the three musketeers' as the author calls, and they are still on the political scene today. The question is about the reliability of official sources. As Ekici tells us, his articles were rejected by international academic journals on the basis of using official data of a state, whose existence and rightness is not recognized. That's why Ekici discusses the reliability of data sources as he engages with each topic. However, if the bibliography used in this book is reviewed without 
prejudice, one can realize that Ekici conducts a very comprehensive research, which absolutely deserves to be read. 